\title{
Assessment of Physico-Chemical Quality of Groundwater by Multivariate Analysis in some Populated Villages nearby Sagar City, MP, India
} Hemant Pathak*

Department of Chemistry, Indra Gandhi Govt. Engineering College, Sagar, Madhya Pradesh, India

\begin{abstract}
Ground water is one of the major resources of the drinking water in rural area nearby Sagar city, Madhya Pradesh. In the present study groundwater quality of the selected 02 villages near by Sagar city were taken for under investigations, by collecting 75 groundwater samples from entire villages and assessed for their suitability for human consumption. Physico-chemical parameters were carried out during different months of the pre monsoon, monsoon and post monsoon seasons in Oct. 2007- July 2011. WHO water directive value is $44 \mathrm{mg} / \mathrm{l}$ for nitrate and $11 \mathrm{mg} / \mathrm{l}$ nitrate in drinking water. $\mathrm{pH}$ values of all samples were between 5.5-8.5 limits. Conductivity of all samples was below WHO water standards. The statistical analysis of the experimentally estimated water quality parameters on water samples yielded the range of the variation, mean, standard deviation, co-efficient of variation, correlation analysis and principal component analysis.
\end{abstract}

Keywords: Groundwater; Physico-chemical quality; Principal component analysis

\section{Introduction}

Ground water is the major source of water for drinking, agricultural, and industrial desires. The availability of water determines the location and activities of humans in an area and our growing population is placing great demands upon natural fresh water resources.

The physico-chemical contaminants that adversely affected the quality of groundwater is likely to arise from a variety of sources, including land application of agricultural chemicals and organic wastes, infiltration of irrigation water, septic tanks, and infiltration of effluent from sewage treatment plants, pits, lagoons and ponds used for storage.

In this study, physico-chemical assessment of ground water samples is determined by using standard analytical methods. The objective of the study is to analyze the 14 parameters of water along 15 locations of 2 villages nearby Sagar city for 3 season's pre monsoon, monsoon and post monsoon (during 2007 - 2011). The aim of this study was to determine the physico-chemical analysis of groundwater sources of Banda and Karrapur village area and to compare with levels obtained with the and WHO drinking water directive.

\section{Study area and collection of water samples}

Ground water samples were collected from in and around Sagar city. Each water sample was taken every month during Oct. 2007- July 2011. Hemant Pathak et al [1-21], worked in the physico-chemical investigations of water from 7 years. The samples were collected in prewashed (with detergent, diluted $\mathrm{HNO}_{3}$ and doubly de-ionized distilled water, respectively) clean polythene bottles without any air bubbles and tightly sealed after collection and labeled in the field. The temperatures of the samples were measured in the field on the spot at the time of sample collection. The samples were immediately analysed in the chemistry lab to minimize physicochemical changes.

\section{Experimental}

\section{Physico-chemical Analysis}

All the chemicals used were of AR grade. Analysis was carried out for various water quality parameters which were measured by using Standard APHA methods.
Banda and Karrapur village area nearby Sagar city was chosen as study area. 15 locations of 2 villages were selected based on domestic, agricultural and industrial activities. Water samples were collected from 15 stations by using standard methods (APHA). Various water samples were collected in clean and dry polyethylene bottles from bore wells after running them for 5 minutes. All the collection of samples are immediately preserved in dark boxes and processed for the different analysis within 6 hours after collection. All water samples were collected in sterile bottles ( 5 liter).

In order to quantitatively analyse and confirm the relationship among major and trace element contents in groundwater samples, Pearson's correlation analysis was applied to the data. Correlations among various metal contents, major elements, EC and $\mathrm{pH}$ in groundwater samples are calculated. Significant positive correlations among various elements in groundwater samples are evident. $\mathrm{Na}$, $\mathrm{Cl}, \mathrm{K}$ and $\mathrm{Mg}$ are significantly correlated $(0.69<\mathrm{r}<0.96)$. The strong correlation between $\mathrm{Na}$ and $\mathrm{Cl}(\mathrm{r}=0.96)$, indicate a common chemical behavior. $\mathrm{Ca}$ and $\mathrm{Mg}$ are not significantly correlated (0.08) indicating that $\mathrm{Ca}$ and $\mathrm{Mg}$ are not probably related to dissolution of low magnesium carbonate, or dolomite deposits. Major elements such as $\mathrm{Na}, \mathrm{Cl}, \mathrm{K}$, and $\mathrm{Mg}$ display significant correlation with $\mathrm{EC}(0.64<\mathrm{r}>0.95)$. This reflects the fact that EC of groundwater is strongly controlled by $\mathrm{Cl}$ and $\mathrm{Na}$ content.

\section{Interpretation of PCA results}

Before applying the above finding, its scientific reliability must be validated using other independent methods. One way to achieve this goal is to compare the water quality data with and without the 4

${ }^{*}$ Corresponding author: Hemant Pathak, Department of Chemistry, Indra Gandhi Govt. Engineering College, Sagar, Madhya Pradesh, India, E-mail: hemantp1981@yahoo.co.in

Received November 22, 2011; Accepted May 28, 2012; Published May 30, 2012

Citation: Pathak H (2012) Assessment of Physico-Chemical Quality of Groundwater by Multivariate Analysis in some Populated Villages nearby Sagar City, MP, India. J Environ Anal Toxicol 2:144. doi:10.4172/2161-0525.1000144

Copyright: (c) 2012 Pathak H. This is an open-access article distributed under the terms of the Creative Commons Attribution License, which permits unrestricted use, distribution, and reproduction in any medium, provided the original author and source are credited. 
Citation: Pathak H (2012) Assessment of Physico-Chemical Quality of Groundwater by Multivariate Analysis in some Populated Villages nearby Sagar City, MP, India. J Environ Anal Toxicol 2:144. doi:10.4172/2161-0525.1000144

Page 2 of 5

nonprincipal physico-chemical parameters. In the first case, data from the principal physico-chemical parameters were used to formulate the following four relationships by regression analysis. The R2 value for the regression equation $(\mathrm{Y}=1.34+1.564 \mathrm{X})$ for data of all the 8 physicochemical parameters was 0.9658 , whereas the $\mathrm{R} 2$ value for the regression equation $(\mathrm{Y}=-1.76+1.323 \mathrm{X})$ for data of the 3 principal parameters was 0.9134

\section{Verification of the PCA results}

The results of PCA were compared with those of cluster analysis and the factor analysis applied to the original data set. CA was performed by means of the Ward's method because of the same reason given above. The dendrogram manifested almost the same clusters compositions as it was found in Figure 4. It also confirms that PC1 and PC2 contain parameters which are most important for the water quality characterization.

\section{Results}

Table 3 and Table 4 represented statistical evaluation for different parameters in the ground water samples of Banda village and Karrapur villages of Sagar city. Ground water quality parameters of Banda village can be concluded that variables-TDS, TH are slightly higher and Alkalinity, $\mathrm{Cl}$ are lower in the post monsoon period than in the

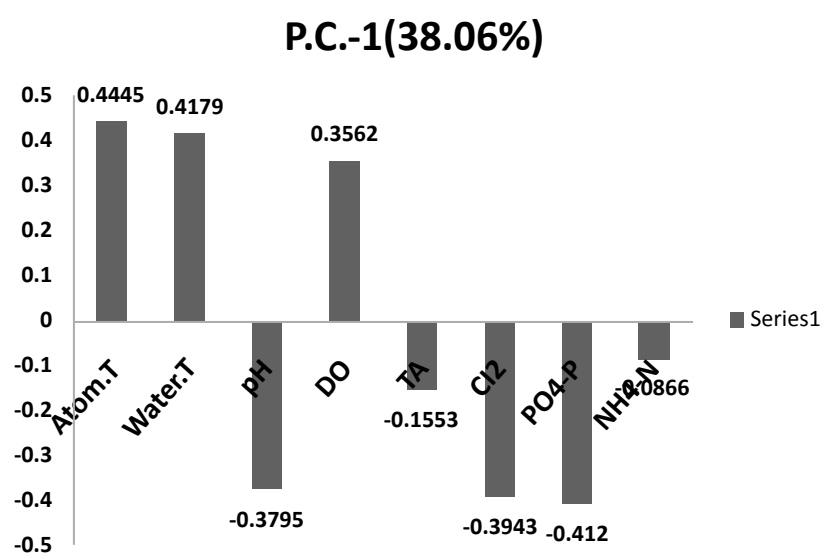

Figure 1: Component loading for the first component (PC1).

\section{P.C.-2(20.00\%)}

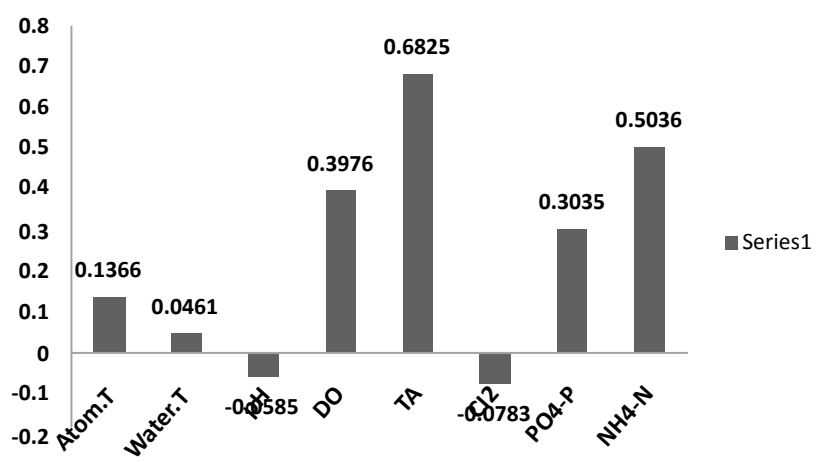

Figure 2: Component loading for the second component (PC2).

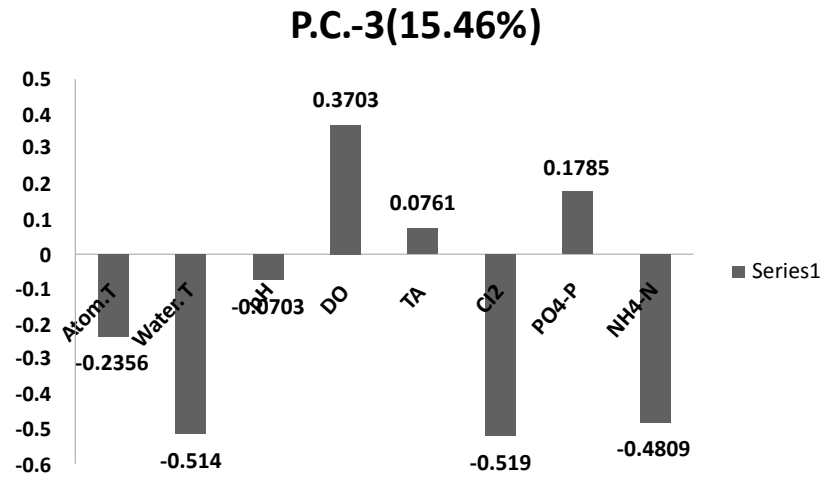

Figure 3: Component loading for the third component (PC3).

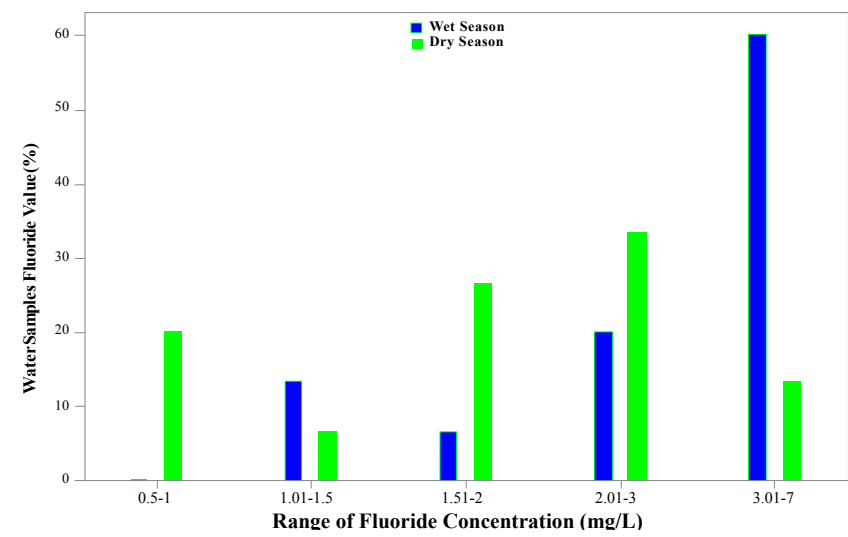

Figure 4: Ranges of fluoride concentration in wet and dry seasons.

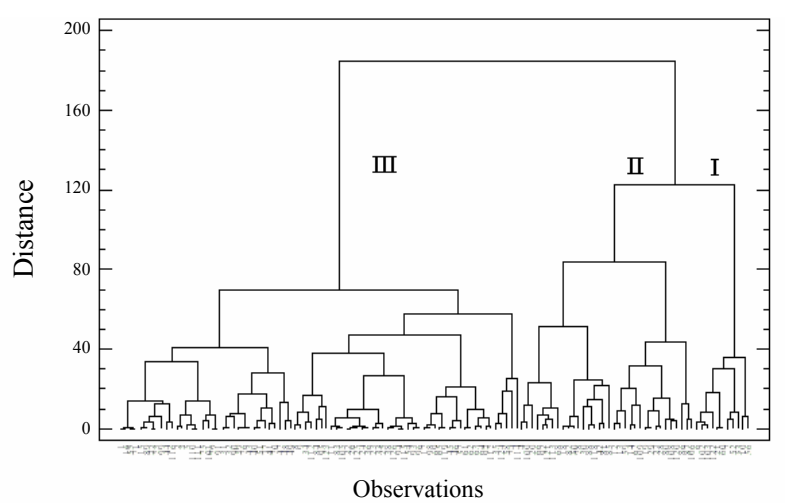

Figure 5: Ward's dendrogram of the drinking water samples defined by the principal components.

PreMonsoon. On the other hand parameters-BOD, COD, Ammonia and Nitrate are clearly higher in all the season showed a clear cut temporal effect. BOD is out of the highest desirable limit or maximum permissible limit set by WHO except $\mathrm{TH}$, Alkalinity and conductivity which recorded high values. It was reported that groundwater was contaminated from nitrate fertilizers and manures used in agriculture. Hence, these sample water can be absolutely fit for drinking after disinfectants treatment. Results of the analysis of groundwater revealed that a total of 30 samples had slightly more $\mathrm{pH}$ levels as per Indian standards. Possible sources of this contamination may be intensive 
Citation: Pathak H (2012) Assessment of Physico-Chemical Quality of Groundwater by Multivariate Analysis in some Populated Villages nearby Sagar City, MP, India. J Environ Anal Toxicol 2:144. doi:10.4172/2161-0525.1000144

$\begin{array}{ll}\text { S.N. } & \text { Parameters } \\ 1 & \mathrm{pH} \\ 2 & \text { Dissolved Oxygen (DO) } \\ 3 & \text { Biochemical Oxygen Demand ( } \\ & \\ 4 & \text { Chemical Oxygen Demand } \\ 5 & \\ & \text { Conductivity } \\ 6 & \\ & \text { Alkalinity } \\ 7 & \\ 8 & \text { Total dissolved Solids } \\ 9 & \text { Chloride } \\ 10 & \text { Orthophosphate }\left(\mathrm{PO}_{4}{ }^{3-}-\mathrm{P}\right) \\ 11 & \text { Nitrate -Nitrogen }\left(\mathrm{NO}_{3}-\mathrm{N}\right) \\ 12 & \text { Ammonia-Nitrogen }\left(\mathrm{NH}_{3}-\mathrm{N}\right) \\ 13 & \text { Total Hardness as } \mathrm{CaCO}_{3} \\ 14 & \text { Fluoride } \\ & \text { Iron }\end{array}$

\begin{tabular}{|c|c|}
\hline Unit & Test Methods \\
\hline - & $\mathrm{pH}$ meter \\
\hline $\mathrm{mg} / \mathrm{L}$ & Winkler method \\
\hline $\mathrm{mg} / \mathrm{L}$ & 5 days incubation at $20^{\circ} \mathrm{C}$ and titration of initial and final $\mathrm{DO}$. \\
\hline $\mathrm{mg} / \mathrm{L}$ & Open Reflux Method \\
\hline $\mathrm{ms} / \mathrm{cm}$ & Conductivity meter \\
\hline $\mathrm{mg} / \mathrm{L}$ & Titration \\
\hline $\mathrm{mg} / \mathrm{L}$ & Digital conductivity meter (LT-51) \\
\hline $\mathrm{mg} / \mathrm{L}$ & Argentometric titration \\
\hline $\mathrm{mg} / \mathrm{L}$ & Ammonium molybdate ascorbic acid reduction method \\
\hline $\mathrm{mg} / \mathrm{L}$ & Spectrophotometric method \\
\hline $\mathrm{mg} / \mathrm{L}$ & Spectrophotometric (Phenate method) \\
\hline $\mathrm{mg} / \mathrm{L}$ & EDTA titration \\
\hline $\mathrm{mg} / \mathrm{L}$ & Colorimetric Method \\
\hline $\mathrm{mg} / \mathrm{L}$ & Colorimetric Method \\
\hline
\end{tabular}

Table 1: List of Chemical parameters and their test methods.

\begin{tabular}{|c|c|c|c|}
\hline Parameter & PC1 & PC2 & PC3 \\
\hline Alkalinity & 0.31881 & -0.41704 & -0.12066 \\
\hline Ammonia & -0.10772 & 0.06600 & -0.05462 \\
\hline Calcium & 0.43365 & -0.15237 & -0.10097 \\
\hline COD & -0.29351 & -0.07623 & -0.13840 \\
\hline Colour & -0.08028 & -0.24234 & 0.44076 \\
\hline Conductivity & 0.42307 & -0.19351 & -0.11142 \\
\hline Hardness & 0.43420 & -0.17996 & -0.09648 \\
\hline Chlorine & 0.04218 & -0.01864 & -0.18426 \\
\hline Iron & 0.04309 & -0.13804 & 0.52467 \\
\hline o-Phosphate & -0.04226 & -0.06378 & -0.02941 \\
\hline Nitrate & 0.26770 & 0.44664 & 0.13679 \\
\hline Nitrite & -0.09440 & 0.11824 & -0.04021 \\
\hline $\mathrm{pH}$ & -0.23475 & -0.44597 & -0.20023 \\
\hline Temperature & 0.04915 & -0.10005 & 0.14823 \\
\hline Turbidity & 0.04797 & -0.17656 & 0.54698 \\
\hline Eigenvalue & 4.51970 & 2.62920 & 2.39520 \\
\hline Percent of variance & 25.11 & 14.61 & 13.31 \\
\hline Cumulative percentage & 25.11 & 39.72 & 53.02 \\
\hline
\end{tabular}

Table 2: Principal component axis data.

agriculture and urbanization in Karrapur and Banda village. In rural areas drinking water generally supplied groundwater

\section{Conclusion and Recommendation}

From the PCA findings given above, follows that 14 parameters used for the drinking water quality characterization can be replaced by the 3 principal components explaining about $83 \%$ of the data variance: nitrate/pH, iron and ammonia. Regarding the physicochemical properties and hygienic importance of these parameters, only the six of them can be used for the frequent water quality monitoring: Conductivity, nitrate, iron, chloride and nitrite.

FA mostly confirmed the PCA results and, additionally, in the case of alkalinity showed relations between hardness and bicarbonate/ carbonate concentrations. The first two principal components explaining about $50 \%$ of data contain the key variables of the drinking water supply system and nitrate/pH.

The PCA scatter plots and dendrograms were used for the samples clustering. Also the combination of scatter plots and cluster analysis was found to be advantages. The revealed clusters gather the drinking water samples according to their origin (surface and ground water).

Multivariate methods were found to be suitable for reducing the water quality parameters and the determination of relationships among them, and also for the samples clustering, as well. These techniques can be helpful for assessors to obtain a global view on the water quality in any urban or other geographical territory when analysing large data sets without a priori knowledge about them.

The correlation coefficients between Temp and DO (-0.89): There is a negative correlation between and $\mathrm{pH}, \mathrm{Cl}_{2}, \mathrm{PO}_{4}-\mathrm{P}$; Water Temp and 
Citation: Pathak H (2012) Assessment of Physico-Chemical Quality of Groundwater by Multivariate Analysis in some Populated Villages nearby Sagar City, MP, India. J Environ Anal Toxicol 2:144. doi:10.4172/2161-0525.1000144

Page 4 of 5

\begin{tabular}{|c|c|c|c|c|c|c|c|c|c|c|c|c|}
\hline & \multirow{2}{*}{\begin{tabular}{|l|} 
Range \\
Statistic
\end{tabular}} & \multirow{2}{*}{\begin{tabular}{|l|} 
Minimum \\
Statistic \\
\end{tabular}} & \multirow{2}{*}{\begin{tabular}{|l|} 
Maximum \\
Statistic \\
\end{tabular}} & \multirow{2}{*}{$\begin{array}{l}\text { Sum } \\
\text { Statistic }\end{array}$} & \multicolumn{2}{|c|}{ Mean } & \multirow{2}{*}{\begin{tabular}{|l} 
Std. \\
Statistic
\end{tabular}} & \multirow{2}{*}{$\begin{array}{l}\text { Variance } \\
\text { Statistic }\end{array}$} & \multicolumn{2}{|c|}{ Skewness } & \multicolumn{2}{|c|}{ Kurtosis } \\
\hline & & & & & Statistic & Std. Error & & & Statistic & Std. Error & Statistic & Std. Error \\
\hline TEMPRATURE & 4.40 & 23.20 & 27.60 & 513.00 & 25.6500 & .2618 & 1.17092 & 1.371 & -.534 & .512 & -.115 & .992 \\
\hline COLOUR & 9.00 & 12.00 & 21.00 & 315.00 & 15.7500 & .6604 & 2.95359 & 8.724 & .653 & .512 & -.889 & .992 \\
\hline $\mathrm{pH}$ & 1.21 & 7.44 & 8.65 & 162.06 & 8.1030 & .0868 & .38814 & .151 & -.417 & .512 & -.876 & .992 \\
\hline TURBIDITY & 15.00 & 10.00 & 25.00 & 263.00 & 13.1500 & .7789 & 3.48342 & 12.134 & 42.127 & .512 & 6.486 & .992 \\
\hline DO & 3.77 & 4.05 & 7.82 & 129.18 & 6.4590 & .2455 & 1.09805 & 1.206 & -.973 & .512 & -.098 & .992 \\
\hline BOD & 7.55 & 2.74 & 10.29 & 116.42 & 5.8210 & .3733 & 1.66933 & 2.787 & .392 & .512 & 2.009 & .992 \\
\hline COD & 11.79 & 7.85 & 19.64 & 220.72 & 11.0360 & .5636 & 2.52062 & 6.354 & 2.195 & .512 & 6.689 & .992 \\
\hline CONDUCTIVITY & .29 & .40 & .68 & 10.07 & .5034 & .0144 & .06449 & .004 & 1.100 & .512 & 2.245 & .992 \\
\hline ALKALINITY & 220.00 & 105.00 & 325.00 & 4224.00 & 211.2000 & 13.2642 & 59.31947 & 3518.800 & .039 & .512 & -.773 & .992 \\
\hline TS & 157.63 & 278.54 & 436.17 & 6597.16 & 329.8580 & 9.1703 & 41.01093 & 1681.896 & 1.368 & .512 & 1.383 & .992 \\
\hline TSS & 35.81 & 5.64 & 41.45 & 450.70 & 22.5350 & 2.3725 & 10.61000 & 112.572 & .166 & .512 & -.783 & .992 \\
\hline TDS & 175.23 & 242.02 & 417.25 & 6146.46 & 307.3230 & 8.7806 & 39.26811 & 1541.985 & 1.097 & .512 & 2.233 & .992 \\
\hline CHLORIDE & 115.00 & 38.97 & 153.97 & 1373.07 & 68.6535 & 6.5343 & 29.22219 & 853.937 & 1.819 & .512 & 3.485 & .992 \\
\hline RESICHLORINE & .43 & .01 & .44 & 2.98 & .1490 & .0189 & .08441 & .007 & 2.040 & .512 & 7.418 & .992 \\
\hline PHOSPHATE & 3.26 & 1.04 & 4.30 & 36.29 & 1.8145 & .1490 & .66643 & .444 & 2.877 & .512 & 10.681 & .992 \\
\hline NITRATE & 7.86 & .93 & 8.79 & 44.19 & 2.2095 & .3926 & 1.75579 & 3.083 & 3.127 & .512 & 10.972 & .992 \\
\hline AMMONIA & .28 & .11 & .39 & 4.20 & .2100 & .0140 & .06274 & .004 & 1.074 & .512 & 2.281 & .992 \\
\hline TH & 142.22 & 153.34 & 295.56 & 4008.06 & 200.4030 & 8.1028 & 36.23695 & 1313.116 & 1.838 & .512 & 3.038 & .992 \\
\hline TEMP. HARD. & 40.33 & 118.64 & 158.97 & 2791.38 & 139.5690 & 2.4731 & 11.06015 & 122.327 & -.312 & .512 & -.552 & .992 \\
\hline PERM. HARD. & 141.80 & 17.82 & 159.62 & 1216.68 & 60.8340 & 8.6359 & 38.62106 & 1491.586 & 1.666 & .512 & 2.270 & .992 \\
\hline Ca HARDNESS & 113.29 & 113.16 & 226.45 & 3068.52 & 153.4260 & 7.7382 & 34.60647 & 1197.607 & 1.144 & .512 & .387 & .992 \\
\hline Mg HARDNESS & 58.71 & 16.48 & 75.19 & 939.54 & 46.9770 & 3.3730 & 15.08453 & 227.543 & .106 & .512 & -.356 & .992 \\
\hline FLUORIDE & 1.15 & .21 & 1.36 & 18.41 & .9205 & .0893 & .39930 & .159 & -.473 & .512 & -1.203 & .992 \\
\hline IRON & 3.95 & .02 & 3.97 & 24.05 & 1.2025 & .3330 & 1.48903 & 2.217 & 1.081 & .512 & -.696 & .992 \\
\hline Ca CONTENT & 45.41 & 45.35 & 90.76 & 1229.78 & 61.4890 & 3.1016 & 13.87062 & 192.394 & 1.144 & .512 & .387 & .992 \\
\hline Mg CONTENT & 14.27 & 4.00 & 18.27 & 228.22 & 11.4110 & .8198 & 3.66617 & 13.441 & .106 & .512 & -.356 & .992 \\
\hline
\end{tabular}

Table 3: Statistical evaluation for different Parameters in the Ground water Samples of Banda village in Sagar City.

\begin{tabular}{|c|c|c|c|c|c|c|c|c|c|c|c|c|}
\hline & \multirow{2}{*}{\begin{tabular}{|l|} 
Range \\
Statistic
\end{tabular}} & \multirow{2}{*}{\begin{tabular}{|l|} 
Minimum \\
Statistic \\
\end{tabular}} & \multirow{2}{*}{\begin{tabular}{|l} 
Maximum \\
Statistic
\end{tabular}} & \multirow{2}{*}{\begin{tabular}{|l|} 
Sum \\
Statistic \\
\end{tabular}} & \multicolumn{2}{|c|}{ Mean } & \multirow{2}{*}{$\begin{array}{l}\text { Std. } \\
\text { Statistic }\end{array}$} & \multirow{2}{*}{$\begin{array}{l}\text { Variance } \\
\text { Statistic }\end{array}$} & \multicolumn{2}{|c|}{ Skewness } & \multicolumn{2}{|c|}{ Kurtosis } \\
\hline & & & & & Statistic & Std. Error & & & Statistic & Std. Error & Statistic & Std. Error \\
\hline TEMPRATURE & 6.30 & 22.30 & 28.60 & 506.50 & 25.3250 & .3269 & 1.46211 & 2.138 & .091 & .512 & .409 & .992 \\
\hline COLOUR & 14.00 & 10.00 & 24.00 & 298.00 & 14.9000 & .7674 & 3.43205 & 11.779 & 1.179 & .512 & 1.295 & .992 \\
\hline $\mathrm{pH}$ & 1.86 & 6.51 & 8.37 & 148.47 & 7.4235 & .1203 & .53783 & .289 & -.256 & .512 & -.784 & .992 \\
\hline TURBIDITY & 10.00 & 8.00 & 18.00 & 219.00 & 10.9500 & .5452 & 2.43818 & 5.945 & 1.347 & .512 & 2.638 & .992 \\
\hline DO & 4.60 & 3.25 & 7.85 & 118.28 & 5.9140 & .2563 & 1.14626 & 1.314 & -.898 & .512 & .888 & .992 \\
\hline BOD & 7.29 & 3.02 & 10.31 & 104.19 & 5.2095 & .3146 & 1.40701 & 1.980 & 2.424 & .512 & 9.618 & .992 \\
\hline COD & 17.10 & 8.25 & 25.35 & 221.32 & 11.0660 & .8357 & 3.73726 & 13.967 & 3.222 & .512 & 12.033 & .992 \\
\hline CONDUCTIVITY & .33 & .45 & .78 & 11.82 & .5911 & .0186 & .08302 & .007 & .858 & .512 & .464 & .992 \\
\hline ALKALINITY & 174.00 & 104.00 & 278.00 & 3900.00 & 195.0000 & 10.3115 & 46.11427 & 2126.526 & .420 & .512 & -.381 & .992 \\
\hline TS & 227.24 & 281.47 & 508.71 & 7597.52 & 379.8760 & 12.8426 & 57.43397 & 3298.660 & .662 & .512 & -.009 & .992 \\
\hline TSS & 61.87 & 3.36 & 65.23 & 378.92 & 18.9460 & 3.2345 & 14.46497 & 209.235 & 1.756 & .512 & 4.579 & .992 \\
\hline TDS & 201.31 & 274.95 & 476.26 & 7218.60 & 360.9300 & 11.3274 & 50.65748 & 2566.180 & .863 & .512 & .470 & .992 \\
\hline CHLORIDE & 108.75 & 28.64 & 137.39 & 1136.87 & 56.8435 & 5.6457 & 25.24846 & 637.485 & 1.916 & .512 & 4.587 & .992 \\
\hline RESICHLORINE & .26 & .05 & .31 & 2.95 & .1475 & .0156 & .06995 & .005 & .703 & .512 & .032 & .992 \\
\hline PHOSPHATE & 3.13 & 1.51 & 4.64 & 48.50 & 2.4250 & .1366 & .61102 & .373 & 2.536 & .512 & 9.416 & .992 \\
\hline NITRATE & 5.63 & 1.06 & 6.69 & 39.61 & 1.9805 & .2930 & 1.31018 & 1.717 & 2.768 & .512 & 8.778 & .992 \\
\hline AMMONIA & .34 & .11 & .45 & 4.06 & .2030 & .0187 & .08367 & .007 & 1.309 & .512 & 2.595 & .992 \\
\hline $\mathrm{TH}$ & 117.87 & 150.19 & 268.06 & 4130.55 & 206.5275 & 5.9582 & 26.64606 & 710.013 & .366 & .512 & .743 & .992 \\
\hline TEMP. HARD. & 116.09 & 96.60 & 212.69 & 3158.14 & 157.9070 & 6.4247 & 28.73225 & 825.542 & -.304 & .512 & .072 & .992 \\
\hline PERM. HARD. & 76.33 & 14.36 & 90.69 & 972.41 & 48.6205 & 4.2379 & 18.95236 & 359.192 & .060 & .512 & .177 & .992 \\
\hline Ca HARDNESS & 94.69 & 114.36 & 209.05 & 3204.22 & 160.2110 & 6.3270 & 28.29535 & 800.627 & -.101 & .512 & -1.203 & .992 \\
\hline Mg HARDNESS & 56.50 & 18.77 & 75.27 & 926.33 & 46.3165 & 3.6065 & 16.12864 & 260.133 & -.093 & .512 & -.967 & .992 \\
\hline FLUORIDE & 1.35 & .21 & 1.56 & 17.15 & .8575 & .0944 & .42206 & .178 & -.034 & .512 & -1.296 & .992 \\
\hline IRON & 1.94 & .04 & 1.98 & 8.78 & .4390 & .0879 & .39322 & .155 & 3.370 & .512 & 13.666 & .992 \\
\hline Ca CONTENT & 37.95 & 45.83 & 83.78 & 1284.17 & 64.2085 & 2.5359 & 11.34095 & 128.617 & -.101 & .512 & -1.203 & .992 \\
\hline Mg CONTENT & 13.73 & 4.56 & 18.29 & 224.99 & 11.2495 & .8764 & 3.91952 & 15.363 & -.092 & .512 & -.966 & .992 \\
\hline
\end{tabular}

Table 4: Statistical evaluation for different Parameters in the Ground water Samples of Karrapur village in Sagar City. 
Citation: Pathak H (2012) Assessment of Physico-Chemical Quality of Groundwater by Multivariate Analysis in some Populated Villages nearby Sagar City, MP, India. J Environ Anal Toxicol 2:144. doi:10.4172/2161-0525.1000144

$\mathrm{pH}, \mathrm{TA}, \mathrm{Cl}_{2}, \mathrm{PO}_{4}-\mathrm{P} ; \mathrm{pH}$ and $\mathrm{DO}$ respectively. A negative correlation is also shown by $\mathrm{DO}$ with $\mathrm{Cl}_{2}, \mathrm{PO}_{4}-\mathrm{P}$.

It is interesting to observe that a high positive correlation (0.7797) exist between Water Temp and there is hardly any correlation between $\mathrm{PO}_{4}-\mathrm{P}$ and $\mathrm{NH}_{4}-\mathrm{N} ; \mathrm{Cl}_{2}$ and TA respectively.

PCA results show that 5 physico-chemical parameters (Water Temp, $\left.\mathrm{pH}, \mathrm{TA}, \mathrm{Cl}_{2}, \mathrm{NH}_{4}-\mathrm{N}\right)$. Identified as less important in explaining the annual variance of the data set, and therefore could be the non-principal parameters. Identification of less important water quality parameter can be seen in which show component loading (eigenvector) for PC1, PC2 and PC3 respectively.

Thirty groundwater samples collected for physico-chemical analysis of water samples of Karrapur and Banda villages of sagar city. Physico-chemical parameters are out of the highest desirable limit or maximum permissible limit set by IS: 10500 . Hence, these sample water cannot be absolutely fit for directly drinking. Some essential treatment needed to convert in drinkable water.

In conclusion, from the results of the present study it may be said that the people in these rural areas are therefore at higher potential risk. Both villages water is not absolutely fit for directly drinking purpose need treatments to minimize the contamination. It is recommended that water analysis should be carried out from time to time to monitor the rate and kind of contamination.

It is need of human to expand awareness among the people to maintain the cleanness of water at their highest quality and purity levels to achieve a healthy life.

\section{References}

1. Hemant P, Limaye SN (2011) Pollumeter: A Water Quality Index model for the assessment of water quality. Green Pages.

2. Hemant $P$, Limaye $S N$ (2011) Study of seasonal variation in groundwater quality of sagar city (india) by principal component analysis. J chem 8: 2000-2009.

3. Hemant P, Limaye SN (2011) Interdependency between physicochemical water pollution indicators: a case study of river Babus, Sagar, M.P., India. Analele UniversităŃii din Oradea - Seria Geografie 1: 23-29.

4. Hemant $P$, Limaye $S N$ (2011) A mathematical modeling with respect to DO for environmentally contaminateddrinking water sources of Sagar city (M.P.), India: A case study. Ovidius University Annals of Chemistry 22: 87-93.

5. Hemant $P$, Deepak $P$, Limaye SN (2011) Seasonal study with interpretation of the chemical characteristics of water pond in reference to quality assessment: A case study. Analele UniversităŃii din Oradea - Seria Geografie 2: 233-238.

6. Hemant P, Limaye SN (2012) Assessment of Physico-Chemical Quality of Groundwater in rural area nearby Sagar city, MP, India. Advances in Applied Science Research. Pelagia Research Library 3: 555-562.
7. Hemant P, Deepak P, Limaye SN (2012) Studies on the physico-chemical status of two water bodies at Sagar city under anthropogenic Influences. Advances in Applied Science Research 3: 31-44.

8. Multivariate evaluation of fluoride contamination in ground water samples of Sagar city, M.P., India: A case study, Instasci Journal of Chemistry, 2012, 2(1), ISSN: 2277-6931.

9. Ground and Tap water Quality assessment of Sagar city especially in terms of saturation index, THE POLYTECHNIC INSTITUTE OF IAŞI, 2012, Issue LVII (LXI), Fasc. 4. ISSN: $0254-7104$.

10. An water quality index mathematical modeling of water samples of Rajghat water supply reservoir Sagar (M.P.) with respect to total dissolved solids: A regression analysis, THE POLYTECHNIC INSTITUTE OF IAŞI, 2012, Issue LVII (LXI), Fasc. 4. ISSN: $0254-7104$.

11. Hemant P (2012) Assessment of Physico-Chemical Quality of municipal water samples of Makronia sub-urban area of Bundel khand region, India, Analele UniversităNii din Oradea - Seria Geografie 1: 569

12. Participated in 26 th conferences of Indian Council of Chemists held at Dr. H. S Gour University, Sagar on 26th-28th February, 2008.

13. A mathematical modeling for environmentally polluted water soluble impurities: A case study(Proceedings of the $45^{\text {th }}$ Annual convention of chemists and international conference on recent advances in chemistry, Organised by, Indian chemical society Hosted by, Karnataka university , Dharwad November 2327,2008).

14. Assessment of Physico-Chemical Quality of municipal water samples of Sagar city, MP, India, (National Seminar on Soil, Air and Water Resource Management, Organised by, Govt. Auto. Girls P.G. College, Sagar, Sponsored by, U.G.C., New Delhi)

15. Contaminant evaluation of boreholes water (drinking water sources) in Gambhiria village, Sagar (MP), April 2012, National symposium on Advances in Environmental chemistry and green technologies, Organised by RJIT tekanpur, Gwalior, Sponsored by, M.P. Council science and technology, Bhopal.

16. Physico-chemical Analysis of Ground Water Samples of Sagar city with respect to water soluble pollutants (National Seminar of Environment protection \& waste management, Organised by, Govt. P.G. College, Bina, Sponsored by, U.G.C., New Delhi).

17. Statistical Study on Physico-Chemical Parameters and Water Quality assessment of Lakha banzara pond, Sagar (M.P.) (National Seminar of Environment Safety and solid waste management, Organised by, Govt. Arts and Commerce College, Sagar, Sponsored by, U.G.C., New Delhi).

18. Assessment of Physico-Chemical Quality of municipal water samples of Sagar city, MP, India, (National Seminar on Soil, Air and Water Resource Management, Organised by, Govt. Auto. Girls P.G. College, Sagar, Sponsored by, U.G.C., New Delhi)

19. APHA, "Standard methods for the examination of water and waste water", $21 \mathrm{~s}$ edition, American Public Health Association, Washington, DC., USA, 2005.

20. Indian standard drinking water, Specification (First Revision) IS-10500:1991. BIS, New Delhi, India

21. SPSS Advanced Models ${ }^{\mathrm{TM}} 11.0$. 